Vol. 51, z. (1-2) - 1998

$101-117$

\title{
Studium porównawcze cech morfologicznych i produktywności lucerny mieszańcowej (Medicago media Pers.) uprawianej w czystym siewie i w mieszankach $\mathrm{z}$ roślinami motylkowatymi i trawami
}

\author{
Część I. Cechy morfologiczne roślin i struktura łanu w zależności od sposobu siewu
}

\section{TADEUSZ ZAJĄC}

Zakład Szczegółowej Uprawy Roślin, Akademia Rolnicza, Al Mickiewicza 21, 31-120 Kraków

(Otrzymano dn. 29.12.1997)

T. Zając (Academy of Agriculture in Cracow, Department of Plant Cultivation, Al. Mickiewicza 21, 31-120

Cracow, Poland.

\begin{abstract}
The investigation carried out in the years 1994-96 had to aim the analysis of morphological features perennial papilionaceaus plants and grass in pure sowing (6 objects) and mixture ( 3 objects). It was considerated the following morphological features: the number of stem per square metre, mass of single stem, number of leaves on the stem, leaves area of stem in square centimeter and two description of the stand: the number of leaves per square metre and leaves area index in square metre.

The experiment was localited on the degraded chernozem, favourable for good growth of all plants.

As result of carried out investigations it was confirmed that alfalfa headed in cuts and years of cultivation the greatest leaf area of stem and stand in comparison to ather plant species.

In results of species difference and method of sowing the all features was differentiated significantly. Interaction between features of investigated species and descriptions of the stand indicated to considerable greates effects of cut in comparison to the effects cultivation years, which appeared distincd only with respect to the leaves area index of stand. The greater density of plants stem cultivated in mixture in composition with cultivation in pure sowing proved about the co-existence between grass species and papilionaceous plants formed the phytocenosis of mixtures, particulary visible in mixture of alfalfa, clover, festuca and ryegrass.
\end{abstract}




\section{WSTĘP}

Lucernę mieszańcową (Medicago media Pers.) podobnie jak i inne gatunki roślin motylkowatych zaleca się uprawiać w mieszankach z trawami. Omawiając wyniki doświadczeń polowych Jelinowska i Magnuszewska (1994) stwierdzają, że w warunkach polskich do wspólnej uprawy z lucerną szczególnie nadaje się życica trwała, rajgras wyniosły oraz stokłosa uniolowata.

Komponenty mieszanek motylkowatych i trawiastych w czasie wspólnej wegetacji korzystają z różnych zasobów siedliska, dlatego natężenie konkurencji międzygatunkowej ulega zmniejszeniu, a Kunelius i Narasimhalu (1983), Shaeffer i in. (1984), Dancik i Vilček (1984) i B orowiecki (1994) donoszą o nadproduktywności mieszanek w porównaniu do plonowania gatunków w uprawie indywidualnej. Poza rejestracją tego zjawiska, mało jest danych o jego czynnikach sprawczych, na poziomie elementów strukturalnych plonu. Analiza wymiarów cech morfologicznych roślin lucerny mieszańcowej i siewnej (Medicago sativa L.) podejmowana była dotąd sporadycznie a ponadto obejmowała skromny liczebnie zestaw, Zając (1987).

$\mathrm{Na}$ tle innych grup roślin rolniczych, rośliny motylkowate drobnonasienne, wśród nich zwłaszcza lucerna mieszańcowa, zbierane są kilkakrotnie w ciągu roku (pokosy), stąd dodatkowo wymiany cech morfologicznych ulegają modyfikacjom w czasie sezonu wegetacyjnego. Również wieloletność lucerny, właściwość bardzo ceniona przez praktyczne rolnictwo, może modyfikować wartości bezwzględne cech morfologicznych lucerny mieszańcowej, decydujące o produktywności roślin i łanu.

W monografii Staszewskiego (1975) poświęconej lucernom znajdują się informacje, że takie cechy morfologiczne jak wysokość roślin, rozgałęzienie, typ wzrostu, masa pędu mają duże znaczenie w hodowli nowych odmian, dlatego że możliwa jest praca selekcyjna nad nimi, pomimo ich dużej zmienności.

W piśmiennictwie brak jest informacji odnośnie bezwzględnych wymiarów cech morfologicznych roślin lucerny, pochodzących z typowych warunków uprawy polowej.

Celem przeprowadzonych badań była ocena zagęszczenia pędów ich masy oraz wysokości i ulistnienia w warunkach różnych sposobów siewu, uwzględniająca lata użytkowania i poszczególne w nich pokosy. Zasięg porównań poszerzono o uprawę indywidualną gatunków wchodzących w skład mieszanek z lucerną mieszańcową.

\section{MATERIAŁ I METODY}

Materiał roślinny obejmujący 9 obiektów pochodził z doświadezeń polowych prowadzonych w latach 1993-96 w Stacji Doświadczalnej ZSzUR w Prusach k. Krakowa.

Schemat doświadczenia obejmował 9 obiektów, z czego 6 wysiano w czystym siewie, a 3 stanowiły mieszanki. Uwzględniono następujące obiekty w czystym siewie (gatunek, ,odmiana”): 1 - lucerna mieszańcowa „Kama”, 2 - koniczyna czerwona „Nike”, 3 - esparceta siewna „,Skrzeszowicka”, 4 - komonica zwyczajna „Bursztyn”, 5 - kostrzewa łąkowa „Skrzeszowicka”, 6 - życica trwała „Nadmorski”. Dalsze trzy obiekty stanowiły mieszanki w których udział komponenta motylkowa- 
tego i trawiastego w czasie siewu był równy i wynosił zawsze po $50 \%$, a dobór gatunków był następujący w kolejnych obiektach: 7 lucerna mieszańcowa $-50 \%+$ kostrzewa tąkowa $25 \%$ + życica trwała $25 \%, 8$ - lucerna mieszańcowa $25 \%+$ koniczyna czerwona $25 \%$ + kostrzewa łąkowa $25 \%$ + życica trwała $25 \%, 9$ - lucerna mieszańcowa $12,5 \%$ + koniczyna czerwona $12,5 \%$ + esparceta siewna $12,5 \%$ + komonica zwyczajna $12,5 \%$ + kostrzewa łąkowa $25 \%$ + życica trwała $25 \%$.

Kiełkujące nasiona roślin motylkowatych i traw wysiano siewnikiem rzędowym „Bratek” w ilości 1000 sztuk na $1 \mathrm{~m}^{2}$. Rozstawa rzędów wynosiła $15 \mathrm{~cm}$, a roślinę ochronną stanowił owies, zebrany w drugiej dekadzie czerwca. Nawożenie i pielęgnację roślin prowadzono zgodnie z zasadami agrotechniki. Glebę pola doświadczalnego stanowił czarnoziem zdegradowany, wytworzony na lessie i zaliczany do kompleksu pszennego bardzo dobrego. Właściwości gleby w połączeniu z sumą opadów w latach 1993-1996 wynoszącą odpowiednio 206, 347, 385 i $478 \mathrm{~mm}$ pozwalają na wysunięcie stwierdzenia, że warunki siedliskowe dla lucerny mieszańcowej i porównywanych na jej tle innych gatunków wieloletnich roślin były sprzyjające wzrostowi, bowiem nie notowano wystąpienia szkód mrozowych, ani żadnych innych.

W czasie zbioru roślin na paszę, którą wyznaczała faza początku kwitnienia lucerny mieszańcowej, liczono pędy roślin motylkowatych i komponentów mieszanek na powierzchni $1 \times 0,5 \mathrm{~m}$, a traw $0,5 \times 0,5 \mathrm{~m}$, a na $1-2$ kilogramowych próbach mieszanek dokonano analizy botaniczno-wagowej.

Analizy morfologiczne prowadzono na 10 pędach każdego gatunku z uprawy indywidualnej oraz po $10 \mathrm{z}$ mieszanek i obejmowały: wysokość i masę pędu, liczbę i powierzchnię liści, które mierzono przy pomocy planimetru firmy Li-Cor model 3100. W oparciu o liczbę pędów na $1 \mathrm{~m}^{2} \mathrm{i}$ ich indywidualną powierzchnię wyliczono liczbę liści na $1 \mathrm{~m}^{2} \mathrm{i}$ indeks powierzchni liści $\left(\mathrm{m}^{2} \times \mathrm{m}^{2}\right)$.

Wysokość pędów i ich ulistnienie w odniesieniu do lucerny mieszańcowej i obu gatunków traw przedstawiono graficznie na rysunkach. Odwzorowano wiernie wysokość pędów i ich ulistnienie oraz zagęszczenie na długości $1 \mathrm{mb}$. Ze względów edytorskich rysunki ograniczono wyłącznie do lucerny mieszańcowej i traw, pomijając pozostałe gatunki roślin motylkowatych i mieszanki.

Analizę statystyczną cech morfologicznych i charakterystyk łanu wykonano w oparciu o jednoczynnikową i wieloczynnikową analizę wariancji, wykorzystującą modele stały i mieszany (lata stanowiły czynnik losowy). Na podstawie analizy istotnych źródeł zmienności, można wskazać, że głównie zmienność cech stanowiły rośliny (gatunki i mieszanki) od 30 do $50 \%$, następnie pokosy od 25 do $40 \%$, oraz interakcje pomiędzy nimi od 7 do $15 \%$. Ze względu na niewielką zmienność wyników doświadczenia w latach, w pracy podano średnie z lat.

\section{OMÓWIENIE WYNIKÓW}

W tabeli 1 zamieszczono wartości liczbowe niektórych cech, najsilniej wiążące się z plonowaniem i jego dynamiką w ciągu roku. Obsada pędów i ich jednostkowa masa determinują wysokość plonu zielonej i suchej masy. Porównywane gatunki roślin motylkowatych i traw wykształcały istotnie zróżnicowaną obsadę pędów na 
powierzchni $1 \mathrm{~m}^{2}$, zależną od biologicznych właściwości gatunku. Wśród traw szczególnie życica trwała odznaczała się wysokim zagęszczeniem pędów, przy czym ich jednostkowa masa była najmniejsza. Spośród roślin motylkowatych komonica zwyczajna posiadała najwięcej pędów na $1 \mathrm{~m}^{2}$, a ich masa była porównywalna z wykształconymi przez kostrzewę łąkową. Wysokoproduktywne gatunki spośród motylkowatych - lucerna mieszańcowa i koniczyna czerwona wykształcały dosyć dużą obsadę pędów, które równocześnie odznaczały się dużą masą, szczególnie odnosi się to do lucerny. Duża masa pędów lucerny ma związek z ich ulistnieniem, mierzonym liczbą liści znajdujących się na pędzie jak i ich całkowitą powierzchnią. Pod względem wartości tych cech żaden z badanych gatunków nie dorównuje lucernie mieszańcowej. Liczba liści na $1 \mathrm{~m}^{2}$ była wypadkową obsady pędów i liczby liści występujących na pojedynczym pędzie a najwyższą wartość tej cechy stwierdzono u lucerny mieszańcowej. Kostrzewa łąkowa i esparceta wykształciły prawie siedem razy mniejszą liczbę liści na jednostce powierzchni, w porównaniu do lucerny.

Tabela 1 - Table 1

Wymiary wybranych cech morfologicznych pędu roślin motylkowatych i traw w czystym siewie

Value of indicated morphological traits of stem papilionateus plants and grass in pure stand

\begin{tabular}{|c|c|c|c|c|c|}
\hline \multirow{5}{*}{ Gatunek - Species } & \multicolumn{5}{|c|}{ Cechy - Traits } \\
\hline & \multirow{4}{*}{\begin{tabular}{|c|} 
Obsada pędów \\
szt/m² \\
Stem density \\
pieces per sq. $\mathrm{m}$.
\end{tabular}} & \multirow{4}{*}{$\begin{array}{c}\text { Powierzchnia liści } \\
\text { pẹdu }-\mathrm{cm}^{2} \\
\text { Leaves area from } \\
1 \mathrm{stem} \mathrm{cm}^{2}\end{array}$} & \multirow{4}{*}{$\begin{array}{l}\text { Masa pędu - g } \\
\text { Mass of stem } \\
-\mathrm{g}\end{array}$} & \multicolumn{2}{|c|}{ Liczba liści } \\
\hline & & & & na pędzie & na $m^{2}$ \\
\hline & & & & \multicolumn{2}{|c|}{ Number of leaves } \\
\hline & & & & per stem & per sq. m. \\
\hline Medicago media Pers & $368 \mathrm{c}$ & $96.3 \mathrm{e}$ & $7,0 \mathrm{e}$ & $22,8 \mathrm{e}$ & $8663 \mathrm{~d}$ \\
\hline Trifolium pratense $\mathrm{L}$. & $316 \mathrm{~b}$ & $86,7 \mathrm{~d}$ & $6,4 \mathrm{~d}$ & $9,1 \mathrm{c}$ & $2586 b$ \\
\hline Onobrychis sativa Lam. & $197 \mathrm{a}$ & $50.7 \mathrm{c}$ & $4,2 \mathrm{c}$ & $5,2 \mathrm{~b}$ & $1144 a$ \\
\hline Lotus corniculatus $L$. & $494 \mathrm{e}$ & $35,3 \mathrm{~b}$ & $3,1 b$ & $14,7 \mathrm{~d}$ & $7431 \mathrm{c}$ \\
\hline Festuca pratensis Huds. & $412 \mathrm{~d}$ & $11,2 \mathrm{a}$ & $2,9 b$ & $3,0 \mathrm{a}$ & $1236 \mathrm{a}$ \\
\hline Lolium perenne $L$. & $660 \mathrm{f}$ & $5,9 \mathrm{a}$ & $1,6 \mathrm{a}$ & $3,8 \mathrm{ab}$ & $2607 \mathrm{~b}$ \\
\hline \multicolumn{6}{|l|}{ Pokosy-Cuts } \\
\hline I & $543 \mathrm{c}$ & $61.6 \mathrm{c}$ & $6,0 \mathrm{c}$ & $11,3 \mathrm{~b}$ & $5787 \mathrm{c}$ \\
\hline II & $39 \mathrm{lb}$ & $52,4 \mathrm{~b}$ & $3,9 \mathrm{~b}$ & $9,3 \mathrm{a}$ & $3607 b$ \\
\hline II & $289 \mathrm{a}$ & $29,1 \mathrm{a}$ & $2,7 \mathrm{a}$ & $8,7 \mathrm{a}$ & $2439 \mathrm{a}$ \\
\hline
\end{tabular}

Średnie dla gatunków i pokosów oznaczone różnymi literami są istotnie zróźnicowane

Mean for species and cuts indicated by different lethers are bifferenced significantly.

Z pokosu na pokos obserwowano zmniejszanie się wartości poszczególnych cech roślin. Wysokość i ulistnienie pędów lucerny mieszańcowej w pokosach i latach użytkowania przedstawiono na rysunku 1. Analiza morfologiczna roślin dostarcza dowodów, że pojedyncze pędy lucerny mieszańcowej uprawianej w mieszance z kostrzewą łąkową i życicą trwałą (obiekt 7) miały więcej liści na pędzie, które wyrastały równomiernie na całej długości pędu. Również na tych pędach częściej pojawiały się zawiązki pędów bocznych, a same pędy główne posiadały tendencję do ograniczania wysokości, począwszy od drugiego roku wegetacji. Na rysunku 2. przedstawiono faktyczną liczbę pędów na długości $1 \mathrm{mb}$ lucerny mieszańcowej i obu gatunków traw w siewie czystym z uwzględnieniem wysokości. Również wartości tych cech w odniesieniu do lucerny są wyższe niż stwierdzone dla traw. 


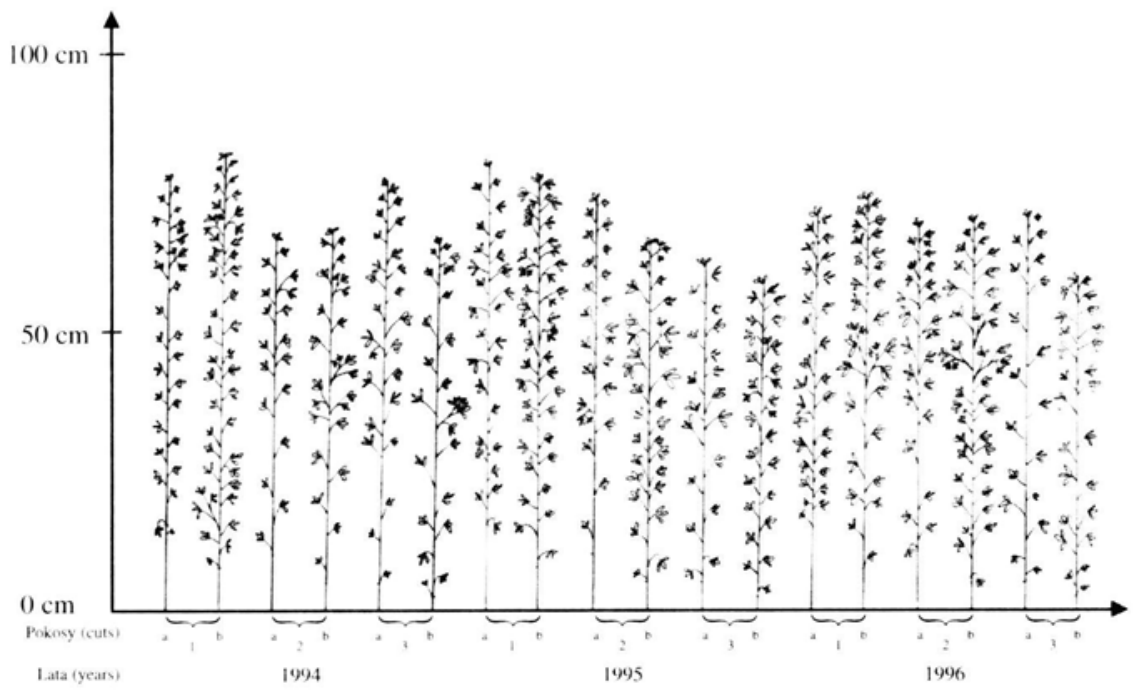

Rys. 1. Porównanie pędu lucerny mieszańcowej uprawianej w czystym siewie (a) i w mieszance z kostrzewą łąkową i życicą trwałą (b)

Fig. 1. Comparison of alfalfa stem cultivated in pure sowing (a) and in mixture with grasses (b)
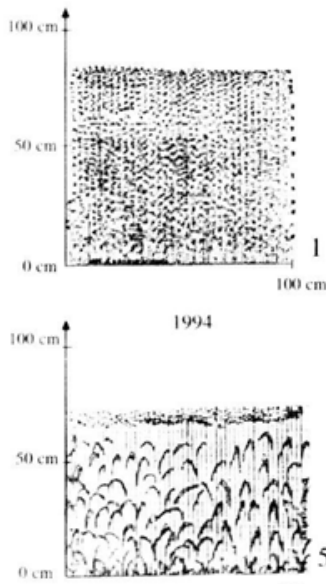

$100 \mathrm{~cm}$
Medicago media Pers.

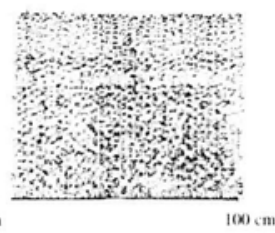

1995

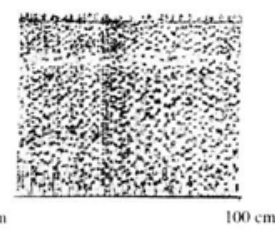

1996

Festuca Pratensis $L$.
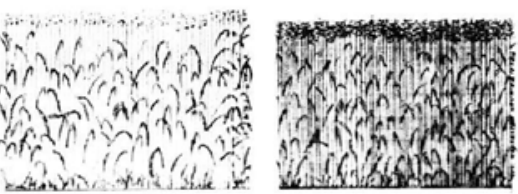

$(0 \mathrm{c}) \mathrm{cm}$
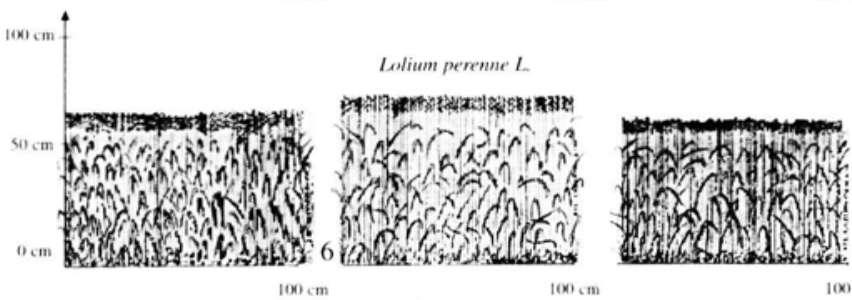

$100 \mathrm{ct}$

$100 \mathrm{~cm}$

Rys. 2. Wysokość i obsada pędów na metrze bieżącym rzędu w pierwszym pokosie, rośliny: 1. Medicago media Pers. 5. Festuca pratensis Huds 6. Lolium perenne L.

Fig. 2. Height and stem density on running metre of rows in first cut: 1. Medicago media Pers. 5. Festuca pratensis Huds 6. Lolium perenne L. 
Analiza struktury przestrzennej łanu porównywanych gatunków tylko w pierwszym pokosie kolejnych lat wegetacji (pełnego użytkowania) wskazuje na przewagę rośliny (lucerna) mającej do swej dyspozycji dużo więcej azotu niż trawy, dzięki symbiozie z bakteriami (Rhizobium meliloti), które jak wykazał (B erling e r 1984) rocznie wiążą od 100 do $500 \mathrm{~kg} / \mathrm{ha} / \mathrm{rok}$. Z drugiej strony aby pozyskać $1 \mathrm{~g}$ azotu lucerna musi dostarczyć bakteriom ekwiwalent energetyczny w wysokości $25 \mathrm{~g}$ węglowodanów, niezbędnych dla ich czynności życiowych. Taka symbioza na poziomie chemicznym wymusza na roślinie motylkowatej (lucernie) możliwie szybki rozwój powierzchni liści zarówno rośliny jak i łanu, do czego niewątpliwie przyczynia się równoczesne wystąpienie szybkiego wzrostu pędów i liści. Z drugiej strony ważne jest ich zagęszczenie sięgające do $500-600$ sztuk $1 \mathrm{~m}^{2}$, po to żeby zbiorowa powierzchnia liści roślin i tworzących łan w pełni wykorzystywała energię promieniowania fotosyntetycznie czynnego. Trawy w czystym siewie wobec niższej dostępności azotu w czasie wegetacji, miały wolniejszy wzrost i rozwój, a w konsekwencji znacznie mniejszą masę i powierzchnię pojedynczego pędu (źdźbła), pomimo ich większego zagęszczenia na długości $1 \mathrm{mb}$ rzędu oraz na powierzchni $1 \mathrm{~m}^{2}$.

W tabeli 2 zamieszczono wyniki dotyczące dwóch cech morfologicznych rzutujących bezpośrednio na wysokość plonu nadziemnej masy roślinnej. Zarówno powierzchnia liści jak i masa pojedynczego pędu były w obrębie badanych gatunków istotnie zróżnicowane, a spowodowane to było sposobem siewu oraz kolejnym w roku pokosem.

Uprawa lucerny w siewie mieszanym pozwoliła na uzyskanie większej masy pędu jak i powierzchni liści, w porównaniu do siewu czystego. Podobne tendencje wystąpiły w odniesieniu do kostrzewy łąkowej. Gatunki - koniczyna czerwona, życica trwała wykazały zróżnicowanie podobne, choć nie układające się tak wyraziście jak powyżej omówione. Pozostałe rośliny reagowały bądź niewielkim wzrostem wartości cech (esparceta siewna), lub też uprawa w mieszance w odniesieniu do komonicy rożkowej, spowodowała spadek wartości obu cech, przy uprawie tej rośliny w mieszance. Wskazuje to na oddziaływanie konkurencyjne ze strony komponentów mieszanki, wobec heliofilnego gatunku jakim jest komonica rożkowa, poprzez odcięcie swiatła przez pozostałe gatunki tworzące mieszanki. Na podkreślenie zasługuje fakt, że w fazie początku kwitnienia lucerny mieszańcowej, komonica rożkowa osiągała zawsze fazę pełni kwitnienia, a więc rozwój tego gatunku był szybki i wyprzedzal pod tym względem pozostałe gatunki roślin motylkowatych.

Kształtowanie się masy pędu i jego całkowitej powierzchni liści, podobnie jak i zagęszczenie pędów warunkował sposobu siewu. Zgodnie z oczekiwaniem najwyższe wartości dla tej cechy stwierdzono dla wszystkich gatunków w siewie czystym. Wskazuje to, że obecność roślin towarzyszących (tworzących mieszanki) nie pozwala na nadmierny rozwój rośliny jednego gatunku kosztem pozostałych, lub inaczej że siła konkurencyjna roślin pastewnych uprawy polowej nie jest na tyle duża, aby nie można ich wysiewać w różnogatunkowych zasiewach, przeznaczonych na wieloletnie użytkowanie i dostarczających dużych ilości taniego i wartościowego białka dla przeżuwaczy. 
Analizując wartości bezwzględne trzech cech morfologicznych omówionych w tabelach 2 i 3 można dostrzec rysujące się wpływy wzajemnych oddziaływań. Zastąpienie $50 \%$ udziału lucerny mieszańcowej w mieszance 7 , dodatkiem koniczyny czerwonej w ilości $25 \%$ poprawiło zdecydowanie warunki troficzne dla traw, szczególnie życicy trwałej. Przedstawienie wzajemnych oddziaływań gatunków tworzących fitocenozę mieszanek poprzez analizę wymiarów cech morfologicznych roślin i charakterystyk łanu (zagęszczenie pędów na powierzchni $1 \mathrm{~m}^{2}$ ) to kwestia złożona i trudna zarazem.

Tabela 2 - Table 2

Porównanie pędów gatunków pod względem masy (B) i powierzchni liści (C) w zależności od sposobu siewu i pokosu (średnie z 3 lat)

Comparison of species stem with regor as depending on the mass (B) and leaves area (C) sowing method and cuts (mean for 3 years)

\begin{tabular}{|c|c|c|c|c|c|c|c|}
\hline \multirow{4}{*}{$\begin{array}{l}\text { Gatunek } \\
\text { Species }\end{array}$} & \multirow{4}{*}{$\begin{array}{l}\text { Cechy* } \\
\text { Traits* }\end{array}$} & \multirow{4}{*}{$\begin{array}{l}\text { Pokosy } \\
\text { Cuts }\end{array}$} & \multicolumn{5}{|c|}{ Sposób siewu - Method of sowing } \\
\hline & & & \multirow{3}{*}{$\begin{array}{l}\text { Czysty } \\
\text { Pure }\end{array}$} & \multicolumn{4}{|c|}{ Mieszanki** - Mixtures** } \\
\hline & & & & 7 & 8 & 9 & $x$ \\
\hline & & & & \multicolumn{4}{|c|}{ Rośliny motylkowate - Papilionaceaus plants } \\
\hline \multirow{8}{*}{$\begin{array}{l}\text { Medicago } \\
\text { media Pers }\end{array}$} & \multirow[t]{3}{*}{ B } & I & $10,87 \mathrm{~cd}$ & $12.67 \mathrm{~d}$ & $11,20 \mathrm{~d}$ & $12,70 \mathrm{~d}$ & $11,85 \mathrm{c}$ \\
\hline & & II & $5.87 \mathrm{a}$ & $9.14 b c$ & $9.18 \mathrm{bc}$ & $8.63 \mathrm{~b}$ & $8.20 \mathrm{~b}$ \\
\hline & & III & $4.30 \mathrm{a}$ & $4.80 \mathrm{a}$ & $5.44 \mathrm{a}$ & $5,31 \mathrm{a}$ & $4,96 \mathrm{a}$ \\
\hline & & $\bar{x}$ & $7.01 \mathrm{a}$ & $8.86 b$ & $8.61 \mathrm{~b}$ & $8.87 \mathrm{~b}$ & \\
\hline & \multirow[t]{3}{*}{ C } & I & $124,9 \mathrm{~cd}$ & $158,3 \mathrm{de}$ & 144,3 de & $164.7 \mathrm{e}$ & $148,0 \mathrm{c}$ \\
\hline & & II & $103,4 \mathrm{bc}$ & $124.9 \mathrm{~cd}$ & $142.6 \mathrm{de}$ & $127.6 \mathrm{~cd}$ & $124,6 \mathrm{~b}$ \\
\hline & & III & $60.7 \mathrm{a}$ & $76.9 \mathrm{ab}$ & $93.8 \mathrm{abc}$ & $78,9 \mathrm{ab}$ & $77.5 \mathrm{a}$ \\
\hline & & $\bar{x}$ & $96.3 \mathrm{a}$ & $120.0 \mathrm{~b}$ & $126.9 \mathrm{~b}$ & $123.7 b$ & \\
\hline \multirow{8}{*}{$\begin{array}{l}\text { Trifolium } \\
\text { pratense L. }\end{array}$} & \multirow[t]{3}{*}{ B } & I & $7,45 b c$ & - & $10,39 \mathrm{~d}$ & $11.38 \mathrm{~d}$ & $9.74 b$ \\
\hline & & II & $6,95 \mathrm{abc}$ & - & I021d & $9,24 \mathrm{~cd}$ & $8,80 \mathrm{~b}$ \\
\hline & & III & $4,77 \mathrm{a}$ & - & $5,80 \mathrm{ab}$ & $5.13 \mathrm{ab}$ & $5.23 \mathrm{a}$ \\
\hline & & $\bar{x}$ & $6.39 \mathrm{a}$ & - & $8.80 b$ & $8,58 b$ & \\
\hline & \multirow[t]{3}{*}{ C } & I & $99,1 \mathrm{bc}$ & - & $115.4 \mathrm{c}$ & $120.7 c$ & $111.7 \mathrm{~b}$ \\
\hline & & li & $112.8 \mathrm{c}$ & - & $124,0 \mathrm{c}$ & $109,0 \mathrm{c}$ & $115,3 \mathrm{~b}$ \\
\hline & & III & $48,2 \mathrm{a}$ & - & $65,7 \mathrm{ab}$ & $56.4 \mathrm{a}$ & $56.8 \mathrm{a}$ \\
\hline & & $\bar{x}$ & $86.7 \mathrm{a}$ & - & $101,7 \mathrm{a}$ & $95,4 a$ & \\
\hline \multirow{8}{*}{$\begin{array}{l}\text { Onobrychis } \\
\text { sativa Lam. }\end{array}$} & \multirow[t]{3}{*}{ B } & I & $7.80 \mathrm{c}$ & - & - & $10.38 \mathrm{~d}$ & $9.09 \mathrm{c}$ \\
\hline & & II & $3.13 \mathrm{ab}$ & - & - & $4.01 \mathrm{~b}$ & $3.57 \mathrm{~b}$ \\
\hline & & III & $1,82 \mathrm{a}$ & - & - & $1.73 \mathrm{a}$ & $1,78 \mathrm{a}$ \\
\hline & & $\bar{x}$ & $4.25 \mathrm{a}$ & - & - & $5.38 b$ & \\
\hline & \multirow[t]{3}{*}{ C } & I & $75.5 b$ & - & - & $99.1 \mathrm{c}$ & $87,3 b$ \\
\hline & & II & $44.4 \mathrm{a}$ & - & - & $49.1 \mathrm{a}$ & $46,7 \mathrm{a}$ \\
\hline & & III & $32,4 a$ & - & - & $37.4 a$ & $34,9 \mathrm{a}$ \\
\hline & & $\bar{x}$ & $50,7 \mathrm{a}$ & - & - & $61.9 \mathrm{a}$ & \\
\hline \multirow{4}{*}{$\begin{array}{l}\text { Lotus } \\
\text { corniculatus. L. }\end{array}$} & \multirow[t]{3}{*}{ B } & I & $4.58 \mathrm{c}$ & - & - & $3.25 \mathrm{~b}$ & $3.92 \mathrm{c}$ \\
\hline & & II & $2.95 \mathrm{~b}$ & - & - & $1.94 \mathrm{a}$ & $2.44 \mathrm{~b}$ \\
\hline & & III & $1.83 \mathrm{a}$ & - & - & $0.97 \mathrm{a}$ & $1,40 \mathrm{a}$ \\
\hline & & $\bar{x}$ & $3,12 \mathrm{~b}$ & - & - & $2,06 a$ & \\
\hline
\end{tabular}




\begin{tabular}{|c|c|c|c|c|c|c|c|}
\hline & $\mathrm{C}$ & $\begin{array}{c}\text { I } \\
\text { II } \\
\text { III }\end{array}$ & $\begin{array}{l}48,4 \mathrm{~d} \\
37,0 \mathrm{c} \\
20,7 \mathrm{~b}\end{array}$ & $\begin{array}{l}- \\
- \\
-\end{array}$ & $\begin{array}{l}- \\
- \\
-\end{array}$ & $\begin{array}{l}32,7 \mathrm{c} \\
20,3 \mathrm{~b} \\
12,9 \mathrm{a}\end{array}$ & $\begin{array}{l}40,6 \mathrm{c} \\
28,6 \mathrm{~b} \\
16,8 \mathrm{a}\end{array}$ \\
\hline & $\bar{x}$ & & $35,4 \mathrm{~b}$ & - & - & $21.0 \mathrm{a}$ & \\
\hline & & & Trawy - & rass & & & \\
\hline Festuca & B & I & 3,30ab & $4,63 \mathrm{c}$ & $3,45 b$ & $5,00 \mathrm{c}$ & $4,09 \mathrm{c}$ \\
\hline pratensis & & II & $2,88 \mathrm{ab}$ & $3,27 \mathrm{ab}$ & $3,34 \mathrm{ab}$ & $3,37 \mathrm{ab}$ & $3,2 \mathrm{lb}$ \\
\hline Huds. & & III & $2.40 \mathrm{a}$ & $2,86 a b$ & $3.06 \mathrm{ab}$ & $2.73 \mathrm{ab}$ & $2,76 a$ \\
\hline & $\bar{x}$ & & $2,86 a$ & $3,58 \mathrm{~b}$ & $3,28 \mathrm{ab}$ & $3,70 \mathrm{~b}$ & \\
\hline & $\mathrm{C}$ & I & $13,4 \mathrm{~b}$ & $14.0 \mathrm{~b}$ & $13,9 \mathrm{~b}$ & $17,6 \mathrm{c}$ & $14,7 \mathrm{~b}$ \\
\hline & & II & $12,1 \mathrm{~b}$ & $15.6 \mathrm{bc}$ & $15,0 \mathrm{bc}$ & $17,9 \mathrm{c}$ & $15,2 \mathrm{~b}$ \\
\hline & & III & $8,0 \mathrm{a}$ & $12,2 \mathrm{~b}$ & $11,9 \mathrm{~b}$ & $14,8 \mathrm{bc}$ & $11,7 \mathrm{a}$ \\
\hline & $\bar{x}$ & & $11,2 \mathrm{a}$ & $13,9 \mathrm{~b}$ & $13,6 \mathrm{~b}$ & $16.8 \mathrm{c}$ & \\
\hline Lolium & B & I & $2,02 \mathrm{bcd}$ & $2,37 \mathrm{cde}$ & $3,18 \mathrm{fg}$ & 2,97efg & $2,63 b$ \\
\hline perenne $\mathrm{L}$. & & II & $1.61 \mathrm{abc}$ & $1,22 \mathrm{a}$ & 2.55def & 2,88 efg & $2,10 \mathrm{a}$ \\
\hline & & III & $1.29 \mathrm{ab}$ & $2.09 \mathrm{~cd}$ & 3,343 & $2,10 \mathrm{~cd}$ & $2.23 \mathrm{a}$ \\
\hline & $\bar{x}$ & & $1.64 \mathrm{a}$ & $1.90 \mathrm{a}$ & $3.05 \mathrm{c}$ & $2,65 b$ & \\
\hline & $\mathrm{C}$ & I & $8,18 \mathrm{abc}$ & $9.54 \mathrm{abc}$ & $37,29 \mathrm{f}$ & $35,6 \mathrm{f}$ & $22,6 \mathrm{~b}$ \\
\hline & & II & $5,08 \mathrm{ab}$ & 13,49abcd & $23,6 \mathrm{e}$ & $34.5 \mathrm{f}$ & $19,2 \mathrm{~b}$ \\
\hline & & III & $4.39 \mathrm{a}$ & $13,92 \mathrm{bcd}$ & $18,77 \mathrm{de}$ & 17.3cde & $13,6 \mathrm{a}$ \\
\hline & $\overline{\bar{x}}$ & & $5.88 \mathrm{a}$ & $12,32 \mathrm{~b}$ & $26.6 \mathrm{c}$ & $29.1 \mathrm{c}$ & \\
\hline
\end{tabular}

Wartości dla cech w obrębie lini oznaczone różnymi literami są istotnie zróżnicowane $(p=0,05)$ Value for traits withing given by lines are measurement with differ lethers are differentiated significantly Cechy* - Traits* - Opis jak w tabeli 1 - Description as table 1

Mieszanki** - Mixtures**: 7 - Medicago media $-50 \%+$ Festuca pratensis $-25 \%+$ Lolium perenne $-25 \%$ 8 - Medicago media $-25 \%+$ Trifolium pratense $-25 \%+$ Festuca pratensis $25 \%+$ Lolium perenne $-25 \%$

9 - Medicago media $-12,5 \%+$ Trifolium pratense $-12,5 \%+$ Onobrychis sativa $-12,5 \%+$ Lotus corniculacus L. $12.5 \%+$ Festuca pratensis $-25 \%+$ Lolium perenne $-25 \%$

Tabela 3 - Table 3

Zagęszczenie pędów roślin motylkowatych i traw w siewie czystym i mieszankach

Stem density of papilonaceus plants and grass in pure sowing and mixtures

\begin{tabular}{|l|c|c|c|c|c|c|}
\hline \multirow{3}{*}{ Gatunek - Species } & & \multicolumn{5}{|c|}{ Sposób siewu - Method of sowing } \\
\cline { 2 - 7 } & Pokosy & Czysty & \multicolumn{4}{|c|}{ Mieszanki - Mixtures } \\
\cline { 4 - 7 } & Cuts & Pure & 7 & 8 & 9 & \\
\hline Medicago media Pers. & I & $452 \mathrm{~h}$ & $248 \mathrm{e}$ & $165 \mathrm{c}$ & $85 \mathrm{a}$ & $237 \mathrm{c}$ \\
& II & $353 \mathrm{~g}$ & $216 \mathrm{~d}$ & $131 \mathrm{~b}$ & $79 \mathrm{a}$ & $195 \mathrm{~b}$ \\
& III & $298 \mathrm{f}$ & $183 \mathrm{c}$ & $130 \mathrm{~b}$ & $84 \mathrm{a}$ & $174 \mathrm{a}$ \\
\cline { 2 - 7 } & $\bar{x}$ & $368 \mathrm{~d}$ & $216 \mathrm{c}$ & $142 \mathrm{~b}$ & $83 \mathrm{a}$ & \\
\hline Trifolium pratense L. & I & $458 \mathrm{e}$ & - & $162 \mathrm{c}$ & $87 \mathrm{ab}$ & $242 \mathrm{c}$ \\
& II & $290 \mathrm{~d}$ & - & $113 \mathrm{~b}$ & $80 \mathrm{a}$ & $161 \mathrm{~b}$ \\
& III & $182 \mathrm{c}$ & - & $105 \mathrm{ab}$ & $82 \mathrm{a}$ & $123 \mathrm{a}$ \\
\cline { 2 - 7 } & $\bar{x}$ & $316 \mathrm{c}$ & - & $128 \mathrm{~b}$ & $83 \mathrm{a}$ & \\
\hline
\end{tabular}




\begin{tabular}{|l|c|c|c|c|c|c|}
\hline Onobrychis sativa Lam. & I & $326 \mathrm{~d}$ & - & - & $59 \mathrm{a}$ & $192 \mathrm{c}$ \\
& II & $164 \mathrm{c}$ & - & - & $30 \mathrm{a}$ & $97 \mathrm{~b}$ \\
& III & $101 \mathrm{~b}$ & - & - & $27 \mathrm{a}$ & $64 \mathrm{a}$ \\
\cline { 2 - 7 } & $\bar{x}$ & $197 \mathrm{~b}$ & - & - & $39 \mathrm{a}$ & \\
\hline \multirow{3}{*}{ Lotus corniculatus L } & I & $602,7 \mathrm{~d}$ & - & - & $95 \mathrm{a}$ & $349 \mathrm{c}$ \\
& II & $497 \mathrm{c}$ & - & - & $74 \mathrm{a}$ & $285 \mathrm{~b}$ \\
& III & $383 \mathrm{~b}$ & - & - & $71 \mathrm{a}$ & $227 \mathrm{a}$ \\
\cline { 2 - 7 } & $\bar{x}$ & $494 \mathrm{~b}$ & - & - & $80 \mathrm{a}$ & \\
\hline Festuca pratensis Huds. & I & $480 \mathrm{f}$ & $264 \mathrm{c}$ & $188 \mathrm{~b}$ & $118 \mathrm{a}$ & $262 \mathrm{~b}$ \\
& II & $411 \mathrm{e}$ & $180 \mathrm{ab}$ & $150 \mathrm{ab}$ & $144 \mathrm{ab}$ & $221 \mathrm{a}$ \\
& III & $345 \mathrm{~d}$ & $179 \mathrm{ab}$ & $117 \mathrm{a}$ & $147 \mathrm{ab}$ & $197 \mathrm{a}$ \\
\cline { 2 - 7 } & $\bar{x}$ & $412 \mathrm{c}$ & $208 \mathrm{~b}$ & $151 \mathrm{a}$ & $137 \mathrm{a}$ & \\
\hline \multirow{3}{*}{ Lolium perenne L. } & I & $923 \mathrm{~g}$ & $356 \mathrm{de}$ & $204 \mathrm{ab}$ & $181 \mathrm{ab}$ & $416 \mathrm{~b}$ \\
& II & $631 \mathrm{f}$ & $379 \mathrm{de}$ & $285 \mathrm{bcd}$ & $229 \mathrm{ab}$ & $381 \mathrm{~b}$ \\
& III & $426 \mathrm{e}$ & $260 \mathrm{bc}$ & $126 \mathrm{a}$ & $201 \mathrm{ab}$ & $253 \mathrm{a}$ \\
\cline { 2 - 7 } & $\bar{x}$ & $660 \mathrm{c}$ & $332 \mathrm{~b}$ & $205 \mathrm{a}$ & $204 \mathrm{a}$ & \\
\hline
\end{tabular}

Opis jak w tabeli 2 - Description as in table 2

Wydaje się jednak, że lepszym przybliżeniem oddziaływań pomiędzy roślinami tworzącymi mieszanki, (złożone z różnej liczby gatunków) jest wykazanie zmian wartości cech w wymiarze względnym (\%). Jednym z podstawowych pytań uprawy roślin, pojmowanej w sposób proekologiczny jest poznanie mechanizmu, wyjaśniającego jak dochodzi przy tym sposobie siewu do zjawiska nadproduktywności gatunków roślin motylkowatych i traw z których zestawiono mieszanki. Od dawna wiadomo, że wzajemna obecność gatunków podnosi plon, lecz poza wskazaniem tego zjawiska, nie podejmowano prób jego wyjaśnienia na poziomie struktury rośliny, czyli analizie wymiarów cech morfologicznych determinujących plon zielonej i suchej masy. Ukazanie zmiany zagęszczenia pędów i ich jednostkowej masy wywołane uprawą w mieszankach na tle uprawy indywidualnej zawierają dane tabeli 4 . W mieszance (7) złożonej z trzech gatunków, równocześnie doszło do wzrostu zagęszczenia pędów obu komponentów mieszanki - motylkowatego (lucerna mieszańcowa) i trawiastego (kostrzewa łąkowa i życica trwała). Przyrost liczby pędów lucerny mieszańcowej był wyraźnie mniejszy niż traw. Zmiany te miały odmienny przebieg w poszczególnych pokosach.

W pierwszym pokosie spośród trzech gatunków mieszanki, kostrzewę łąkową charakteryzował ponad dwukrotnym przyrost liczby pędów, ograniczyło to możliwości wzrostu obsady pędów. Szczególnie stabilne w tej mieszance było zagęszczenie lucerny mieszańcowej, bowiem względny wzrost obsadu pędów tego gatunku wyniósł tylko $10 \%$. W drugim i trzecim pokosie lucerna mieszańcowa i życica trwała pod względem wzrostu zagęszczenia pędów w mieszance na tle siewu czystego zachowały się podobnie, chociaż z różnym skutkiem, bowiem w odniesieniu do rośliny motylkowatej wzrost obsady pędów wyniósł około $20 \%$, podczas gdy odpowiednie wartości dla życicy trwałej wynosiły około $140 \%$, a więc roślina ta zwiększała 7 - krotnie zagęszczenie pędów, w wyniku poprawy warunków troficznych, wywołanych zwiększoną ilością azotu w glebie, pochodzącego z wydzielin korzeniowych i prawdopodobnie rozkładem korzeni wcześniej zanikłych roślin motylkowatych. W drugim 
Tabela $4-$ Table 4

Względne zmiany zagęszczenia (A) i masy pędów (B) roslin motylkowatych i traw w mieszankach ( siew czysty = $100 \%$ )

Relative chauges $(\%)$ of stem density $(A)$ and mass $(B)$ of papilonaceus plants and grass in mixtures (pure sowing $=100 \%$ )

\begin{tabular}{|c|c|c|c|c|c|c|c|c|c|c|c|c|c|}
\hline \multirow{4}{*}{$\begin{array}{l}\text { Gatunek } \\
\text { Species }\end{array}$} & & \multicolumn{12}{|c|}{ Mieszanki - Mixstures } \\
\hline & \multirow{3}{*}{$\begin{array}{l}\text { Pokosy } \\
\text { Cuts }\end{array}$} & \multicolumn{4}{|c|}{7} & \multicolumn{4}{|c|}{8} & \multicolumn{4}{|c|}{9} \\
\hline & & \multicolumn{12}{|c|}{ Cechy - Traits } \\
\hline & & \multicolumn{2}{|c|}{ A } & \multicolumn{2}{|c|}{ B } & \multicolumn{2}{|c|}{ A } & \multicolumn{2}{|c|}{ B } & \multicolumn{2}{|c|}{ A } & \multicolumn{2}{|c|}{ B } \\
\hline \multirow{3}{*}{$\begin{array}{l}\text { Medicago } \\
\text { media Pers }\end{array}$} & 1 & 44.3 & $(9.8)$ & 1.8 & $(16,6)$ & 206.5 & $(45,7)$ & 0.33 & $(3,0)$ & 225,3 & $(49.8)$ & 1.83 & $(16.8)$ \\
\hline & II & 78.8 & $(22,3)$ & 3.27 & $(55,7)$ & 170.8 & $(48,4)$ & 3,31 & $(56.4)$ & 281.2 & $(79.6)$ & 2.76 & $(47.0)$ \\
\hline & III & 67.4 & $(22.6)$ & 0.5 & $(11,6)$ & 220 & $(74,1)$ & 1.14 & $(26.5)$ & 374.0 & $(125,0)$ & 1.01 & $(23.5)$ \\
\hline \multirow{3}{*}{$\begin{array}{l}\text { Trifolium } \\
\text { pratense } L .\end{array}$} & I & - & - & - & - & 191,5 & $(41,8)$ & 2.94 & $(39.5)$ & 238.3 & $(52.0)$ & 3.93 & $(52.8)$ \\
\hline & II & - & - & - & - & 160.5 & $(55,3)$ & 3.26 & $(46.9)$ & 349.7 & $(120.5)$ & 2.29 & $(32.9)$ \\
\hline & III & - & - & - & - & 238,0 & $(130.7)$ & 1.03 & $(21.6)$ & 476,4 & $(261.8)$ & 0,36 & $(7.5)$ \\
\hline \multirow{3}{*}{$\begin{array}{l}\text { Onobrychis } \\
\text { sativa Lam. }\end{array}$} & I & - & - & - & - & - & - & - & - & 146.3 & $(44,9)$ & 2,58 & $(33.1)$ \\
\hline & II & - & - & - & - & - & - & - & - & 78.7 & $(48.1)$ & 0.88 & $(28.1)$ \\
\hline & III & - & - & - & - & - & - & - & - & 115,3 & $(114,5)$ & $-0,09$ & $(-5,0)$ \\
\hline \multirow{3}{*}{$\begin{array}{l}\text { Lotus } \\
\text { corniculatus L. }\end{array}$} & 1 & - & - & - & - & - & - & - & - & 154.9 & $(25.7)$ & -1.33 & $(-29,0)$ \\
\hline & II & - & - & - & - & - & - & - & - & 92,6 & $(18,6)$ & $-1,01$ & $(-34,2)$ \\
\hline & III & - & - & - & - & - & - & - & - & 115.3 & $(87.4)$ & -0.86 & $(-47.0)$ \\
\hline \multirow{3}{*}{$\begin{array}{l}\text { Festuca } \\
\text { pratensis Huds. }\end{array}$} & I & 576 & $(220)$ & 1,33 & $(40,3)$ & 270,8 & $(56.4)$ & 0,15 & $(4,5)$ & -8 & $(-1,7)$ & 1,7 & $(51.5)$ \\
\hline & II & 309 & $(75,2)$ & 0.39 & $(13.5)$ & 189 & $(46.0)$ & 0.46 & $(15.9)$ & 166.2 & $(40.4)$ & 0.49 & $(17.0)$ \\
\hline & III & 372 & $(107,9)$ & 0.46 & $(19.2)$ & 121,8 & $(35.3)$ & 0,66 & $(27.5)$ & 244.2 & $(70,8)$ & 0,33 & $(13,8)$ \\
\hline \multirow{3}{*}{$\begin{array}{l}\text { Lolium } \\
\text { perenne L. }\end{array}$} & I & 502 & $(54,4)$ & 0.35 & $(17.3)$ & -106.1 & $(-11.5)$ & 1.16 & $(57,4)$ & -200.5 & $(-21,7)$ & 0,95 & $(47.0)$ \\
\hline & II & 886 & $(140,6)$ & -0.39 & $(-24,2)$ & 508,1 & $(80,6)$ & 0,94 & $(58,3)$ & 284,1 & $(45,00$ & 1,27 & $(78,9)$ \\
\hline & III & 614 & $(144,3)$ & 0.80 & $(620)$ & 77.1 & $(11.8)$ & 2.14 & $(165.9$ & 379.5 & $(89.1)$ & 0.81 & $(62.8)$ \\
\hline
\end{tabular}


pokosie wystąpiły symptomy konkurencji pomiędzy lucerną mieszańcową a życicą trwałą, w wyniku której masa źdźbeł trawy uległa zmniejszeniu o $24 \%$, podczas gdy dla rośliny motylkowatej wzrost wyniósł ponad $50 \%$.

W mieszankach 8 i 9 do których wprowadzono koniczynę czerwoną, zastępując tym gatunkiem część udziału lucerny mieszańcowej, doszło do ograniczenia zagęszczenia pędów życicy trwałej w pierwszym pokosie. Odmiennie kształtowało się zagęszczenie pędów kostrzewy łąkowej, która w tych mieszankach wzrastała we wszystkich pokosach, w odniesieniu do uprawy indywidualnej tego gatunku. Wskazuje to, że z rolniczego punktu widzenia jest to gatunek traw szczególnie wartościowy i można zalecać jej uprawę w mieszankach. Wprowadzenie koniczyny czerwonej pozwoliło na duży przyrost masy pojedynczego pędu jak i ich obsady na jednostce powierzchni u obu gatunków rośliny motylkowatych. Ten fakt można interpretować jako dowód, że konkurencja wewnątrzgatunkowa w jednogatunkowych zasiewach lucerny mieszańcowej i koniczyny czerwonej, a także kostrzewy łąkowej ma wyższe natężenie w ciągu całego okresu wegetacyjnego w porównaniu do mieszanek złożonych z 3 lub 4 gatunków (mieszanki 7 i 8). Stosunki między 6 gatunkami roślin w mieszance (9) były bardziej złożone, a ich szczegółowa analiza dostarcza dowodów, że stosunki między roślinami miały charakter zarówno koegzystencji jak i konkurencji. W odniesieniu do kształtowania się zagęszczenia pędów roślin motylkowatych we wszystkich pokosach wartość tej cechy wzrasta, a uszeregowanie roślin poczynając od osiągającej największe korzyści z tego typu uprawy przedstawia się następująco koniczyna czerwona $>$ lucerna mieszańcowa $>$ esparceta siewna $>$ komonica rożkowa. W każdym roku badań zagęszczenie źdźbeł w pierwszym pokosie było ograniczone przez gęstą ruń, złożoną wiosną z pędów 1 i 2 - rzędu, wyrastających z szyjek korzeniowych i dolnych odcinków łodyg (zimująca ścierń) roślin motylkowatych. W dalszych pokosach nastąpił wzrost zagęszczenia pędów (źdźbeł) traw, dla obu gatunków bardzo podobny, co niewątpliwie dobitnie pokazuje różnice w rozwoju traw wywołane przez obecność w fitocenozie roślin motylkowatych. We wszystkich mieszankach ilościowy udział komponentów był równy $(50 \%)$, a w mieszankach w których występowały 2 lub 4 gatunki roślin motylkowatych, przyrost zagęszczenia źdźbeł traw był mniejszy niż w mieszance $\mathrm{z}$ jednym gatunkiem rośliny motylkowatej (lucerna mieszańcowa). Spadkowi zagęszczenia źdźeł traw w mieszankach złożonych z większej ilości roślin motylkowatych toważyszył wzrost jednostkowej masy pędu (źdźbła), co wskazuje na element kompensacji występujących pomiędzy elementami struktury plonu masy roślinnej traw. Z kolei u roślin motylkowatych wystąpił względny wzrost masy pędu, aczkolwiek wielkość tego przyrostu była różna i charakterystyczna dla poszczególnych gatunków. Na podstawie uzyskanych wyników odnoszących się do zmian masy pędu można wskazać, że największe korzyści z uprawy w wielogatunkowej mieszance odniosły poza trawami także koniczyna czerwona i lucerna mieszańcowa. Natomiast pędy komonicy zwyczajnej pochodzące $z$ tej mieszanki miały niższą masę pędu w porównaniu do siewu czystego, co dobitnie ukazuje, że wzrost i rozwój tego gatunku w tych warunkach przebiegał gorzej niż pozostałych gatunków roślin motylkowatych.

Wielkość indeksu liściowego roślin motylkowatych i traw w poszczególnych pokosach lat wegetacji pokazuje dwa niezmiernie ważne zjawiska mające związek 
z wartością pokarmową tych roślin jak i możliwościami wykorzystania przez nie energii promieniowania fotosyntetycznie czynnego (tab. 5). Wiadomo, że rośliny motylkowate i trawy uprawiane na paszę gromadzą białko głównie w liściach. Tak więc wielkość powierzchni liści łanu ściśle będzie rzutować na zawartość tego składnika. Porównane w badaniach gatunki i zestawione $\mathrm{z}$ nich mieszanki istotnie różniły się wymiarami powierzchni liściowej. Dla wszystkich obiektów widoczny był spadek powierzchni indeksu liściowego postępujący z pokosu na pokos. Analiza wartości liczbowych indeksu liściowego odnoszących się do konkretnych gatunków i mieszanek wskazuje na przewagę roślin motylkowatych nad trawami. Szczególnie przy porównaniu powierzchni blaszek liści traw z lucerną, wskazuje na wielokrotną (różną w pokosach) przewagę lucerny.

Tabela 5 - Table 5

Indeks powierzchni liściowej $\left(\mathrm{m}^{2} \cdot \mathrm{m}^{2}\right)$ gatunków i mieszanek w latach i pokosach Leaf area index $\left(\mathrm{m}^{2} \cdot \mathrm{m}^{2}\right)$ species and mixtures in years and cut

\begin{tabular}{|c|c|c|c|c|c|c|c|c|c|}
\hline \multirow{4}{*}{$\begin{array}{l}\text { Obiekty } \\
\text { Objects }\end{array}$} & \multicolumn{9}{|c|}{ Lata - Years } \\
\hline & \multicolumn{3}{|c|}{1994} & \multicolumn{3}{|c|}{1995} & \multicolumn{3}{|c|}{1996} \\
\hline & \multicolumn{9}{|c|}{ Pokosy - Cuts } \\
\hline & I & II & III & I & II & III & I & II & III \\
\hline 1 & $7,08 \mathrm{f}$ & $3,94 \mathrm{f}$ & $2,32 \mathrm{f}$ & $4,48 \mathrm{e}$ & $3,40 \mathrm{e}$ & $1,62 \mathrm{c}$ & $5,45 \mathrm{~g}$ & $3,59 \mathrm{f}$ & 1,5 If \\
\hline 2 & $5,02 \mathrm{e}$ & $2,65 \mathrm{~d}$ & $0,78 \mathrm{c}$ & $4,57 \mathrm{e}$ & $3,76 \mathrm{f}$ & $1,06 \mathrm{~b}$ & $4,52 \mathrm{e}$ & $3,54 \mathrm{f}$ & $0,80 \mathrm{~d}$ \\
\hline 3 & $2,85 \mathrm{~b}$ & $0,60 b$ & $0.33 b$ & $2,47 b$ & $0,74 \mathrm{a}$ & 0.28 & $2,08 b$ & $0,85 b$ & $0,37 b$ \\
\hline 4 & $2,88 \mathrm{~b}$ & $1,68 \mathrm{c}$ & $0.63 \mathrm{c}$ & $2,72 \mathrm{c}$ & $1,86 \mathrm{~b}$ & $1,13 b$ & $3,12 \mathrm{c}$ & $1,96 \mathrm{c}$ & $0.62 \mathrm{c}$ \\
\hline 5 & $0,65 \mathrm{a}$ & $0,57 \mathrm{~b}$ & $0.42 b$ & $0.71 \mathrm{a}$ & $0.52 \mathrm{a}$ & $0.30 \mathrm{a}$ & $0.65 \mathrm{a}$ & $0.54 \mathrm{a}$ & $0,20 \mathrm{a}$ \\
\hline 6 & $0,69 \mathrm{a}$ & $0,27 \mathrm{a}$ & $0,16 \mathrm{a}$ & $0,73 \mathrm{a}$ & $0.52 \mathrm{a}$ & $0,25 \mathrm{a}$ & $0,92 \mathrm{a}$ & $0,35 \mathrm{a}$ & $0,35 b$ \\
\hline 7 & $4,02 \mathrm{c}$ & $2,66 \mathrm{~d}$ & $1,40 \mathrm{~d}$ & $3,95 d$ & $2,34 \mathrm{c}$ & $1,65 \mathrm{c}$ & $3,73 \mathrm{~d}$ & $3,10 \mathrm{e}$ & $1,13 \mathrm{e}$ \\
\hline 8 & $4,69 \mathrm{~d}$ & $4,50 \mathrm{~g}$ & $2,38 \mathrm{f}$ & $4,85 \mathrm{f}$ & $3.11 \mathrm{~d}$ & $2.09 \mathrm{e}$ & $5,07 \mathrm{f}$ & $4,80 \mathrm{~g}$ & $2,36 \mathrm{~g}$ \\
\hline 9 & $4.48 \mathrm{~d}$ & $3.46 \mathrm{e}$ & $2.14 \mathrm{e}$ & $3,94 \mathrm{~d}$ & $3.31 \mathrm{de}$ & $1.80 \mathrm{~d}$ & $3,76 \mathrm{~d}$ & $2,80 \mathrm{~d}$ & $1,61 \mathrm{f}$ \\
\hline
\end{tabular}

Nazwy obiektów, patrz tabele 1 i 2 - Description objects see table 1 and 2.

\section{DYSKUSJA}

Badania nad plonowaniem mieszanek lucerny siewnej z trawami były podejmowane stosunkowo często, zwłaszcza w tych rejonach (zasięg winorośli) gdzie uprawa tej rośliny jest podstawowym źródłem biomasy zasobnej w białko, a przeznaczone dla przeżuwaczy, stąd dawniej lucernę nazywano „królową roślin pastewnych”. Praktyczne podejście warunkowało podejmowaniem badań ograniczonych do analiz ilościowych (wysokość plonu zielonej i suchej masy) oraz jakościowych koncentrujących się na analizie chemicznej, głównie zawartości frakcji białka i włókna. Rzadziej produktywność lucerny oceniano poprzez wymiary cech morfologicznych, będących elementami składowymi plonu. Jelinowska i Magnuszewska (1994) optują aby dalsze prace nad regulacją składu mieszanek lucerny z trawami zakładały badanie zjawisk konkurencji w łanie i jej uwarunkowania. Na podstawie badań zestawu 20-30 odmian lucerny siewnej i mieszańcowej (Prochazka i in. 1984) ustalili, że wysokoplenne spośród nich odznaczają się dużą energią wzrostu, zależnej jednak od warunków pogodowych roku uprawy, natomiast masa nasion nie 
miały istotnego wpływu na wielkość plonu. Hruškowa (1994) udowodniła, że plon zielonej masy roślin wyrosłych $\mathrm{z}$ dużych nasion był od $1 \%$ do $6 \%$ wyższy w porównaniu do roślin pochodzących z nasion małych, co zostało statystycznie udowodnione. Z kolei Käding i Kreil (1982) wykazali w doświadezeniach modelowych, że najkorzystniej przebiega kiełkowanie gdy nasiona zostaną wysiane na głębokość $1,5 \mathrm{~cm}$. Warunki w czasie wschodów nasion mają długotrwały wpływ i ujawniają się jak ustaliła B in de rova i Holy (1988) w dalszych latach wegetacji poprzez wytworzoną obsadę roślin zależną od interakcji zachodzącej pomiędzy rokiem, sposobem siewu i odmianą. B in de row a (1985) ustaliła, że zagęszczenie roślin lucerny siewnej i koniczyny czerwonej zależne od warunków wschodów silnie rzutuje w połączeniu z wysokością pędu I i II pokosu na wielkość plonu zielonej i suchej masy. Dodatkowych argumentów świadczących o roli zagęszczenia roślin lucerny na wysokość plonu suchej masy dostarczają Lichner i K hazim (1986) wykazując, że małe zagęszczenie roślin i ich nierównomierne rozmieszczenie na polu (puste miejsca) powodują, że praktyka rolnicza w tych warunkach wykorzystuje tylko od $41 \%$ do $56 \%$ potencjalnej produktywności lucerny.

Przezwyciężeniem tych niedogodności dostrzeganych w czystym siewie są postulaty uprawy roślin motylkowatych w mieszankach $\mathrm{z}$ trawami a najpełniej korzyści płynące $\mathrm{z}$ tak prowadzonej uprawy przedstawił Knoch (1982), wymieniając 10 zalet mieszanek wobec monokulturowej uprawy traw. Borowiecki (1994) podaje, że liczba pędów obu komponentów mieszanek malała w kolejnych latach, aczkolwiek w pokosach miała nieukierunkowany przebieg, w odniesieniu do mieszanek, bowiem w jednych malała, a jednocześnie w innych wzrastała i ponadto uzyskane zagęszczenie w mieszankach w odniesieniu do lucerny było małe i nigdy nie przekroczyło 100 sztuk na $1 \mathrm{~m}^{2}$, co wskazuje że warunki siedliskowe są decydujące.

Trawy jako rośliny pastewne wymagające dużych dawek azotu powinny być uprawiane $\mathrm{w}$ mieszankach $\mathrm{z}$ koniczynami, wówczas jak to wykazali Lehmann i Meister (1982) doszło do zwiększenia masy pędów życicy trwałej z równoczesnym zwiększeniem się zawartości białka w wyniku transferu azotu pomiędzy systemami korzeniowymi wspólnie uprawianych roślin. Rola azotu przekazywanego trawom przez wydzieliny korzeni roślin motylkowatych jest wieloraka i poza zwiększeniem zawartości białka, masy i wysokości źdźbła, obniża równocześnie w nich zawartość suchej masy i powodując większą skłonność do wylegania (Halva i in. 1979).

Kunelius i Narasimhalu (1983) udowodnili, że trawy rosnące w mieszankach otrzymują od komponenta motylkowatego (lucerna siewna, koniczyna czerwona, komonica rożkowa) więcej niż $225 \mathrm{~kg} \mathrm{~N} / \mathrm{ha}$ rocznie, co zwiększa obsadę źdźbet, a w konsekwencji przyczynia się do podniesienia plonowania. Meisen i in. (1983) podają, że $200 \mathrm{~kg} \mathrm{~N} / \mathrm{ha} /$ rok zastosowanego pod życicę wielokwiatową daje plon zbliżony do dostarczonego przez mieszankę życicy z koniczyną bez $\mathrm{N}$. Z uwagi na rosnące koszty produkcji nawozów Major i in. (1979) podjęli poszukiwania mające na celu wyizolowanie lepszych od dotychczasowych szczepów bakterii Rhizobium sp., mogących więcej wiązać azotu i oddawać ten pierwiastek roślinom motylkowatym. Dla gatunków wieloletnich (esparceta, lucerna i traganek pęcherzykowaty, (Astragalus cicer L.) zmienność plonu w $60-71 \%$ była zależna od masy brodawek korzeniowych, bowiem większe wiązanie azotu prowadziło do zwiększenia masy pędu i jego ulistnienia. 
Energię wzrostu roślin motylkowatych poza zaopatrzeniem w azot wiązany biologicznie poprawia też dobre zaopatrzenie gleby w wodę, na poziomie $70 \%$ polowej pojemności i jak dowiedli Li chner i Zapotočny (1984) efekt plonotwórczy $1 \mathrm{~mm} \mathrm{H}_{2} \mathrm{O}$ wyniósł dla koniczyny $\mathrm{i}$ ich mieszanek oraz lucerny odpowiednio $29,96,17,84$ i 17,67 kg suchej masy na ha. Poza ilościowym wyliczeniem autorzy tych badań nie przedstawili zmian struktury plonu. Mieszanki motylkowo-trawiaste, reprezentowane przez koniczynę i lucernę ograniczają występowanie chwastów, a zjawisko to opisują w odniesieniu do Słowacji Dancik i Vilček (1984) i podobne spostrzeżenia w warunkach Minesoty poczynił She affer i in. (1984) i Moyer (1985). Ograniczenie zachwaszczenia przy pomocy herbicydów podniosło plon lucerny i esparcety. Poza zagęszczeniem pędów i ich masą Law i Reeves (1984) dużą rolę w tworzeniu plonu traw przypisują wysokości pędu w pełni kłoszenia. Cechy wiodące w odniesieniu do roślin motylkowatych to wysokość pędu i łączna powierzchnia liści, mierzone w początku zakwitania. Borowiecki (1994) podkreśla, że konkurencja o światło prowadzi do wzrostu wysokości pędów obu komponentów mieszanek.

Zagęszczenie pędów i ich wysokość mogą silnie ograniczać nawroty chłodów, co stwierdziła w warunkach nieczarnoziemnej strefy Rosji Juszkina (1985). Omówione powyżej czynniki zmieniające zagęszczenie pędów i ich wysokość, w konsekwencji prowadzą do zmian wielkości LAI (indeks powierzchni liści) Posypanov i Worankowa (1983) donoszą, że szczególny jest wpływ suszy glebowej, która zmniejsza silnie powierzchnie liści, pędu i łanu oraz o 1,7-1,9\% zawartość białka w masie roślinnej koniczyny. Lucerna jako gatunek wywodzący się ze starożytnej Medii (Iran) jest gatunkiem odpornym na brak wody i jej niedobory nie zaburzają tak łatwo procesów życiowych tej rośliny.

B ow le y i in. (1988) donoszą, że LAI lucerny jest większy niż koniczyny i wynika przede wszystkim z większego zagęszczenia pędów oraz z faktu że gatunek ten w ciągu doby ma wyższą produkcję suchej masy z $1 \mathrm{~m}^{2}(34 \mathrm{~g})$ wobec $(30 \mathrm{~g})$ dostarczanych przez koniczynę. Zwiększenie powierzchni liści lucerny poprzez selekcje i wyprowadzenie lini o większej liczbie niż 3 liski w liściu prowadzi do podniesienia zawartości białka w paszy (Juan i in. 1993). Jak podają Volenec i Cherney (1990) cyt za Juan i in. (1993). obecnie wyprowadzono już linie hodowlane posiadające 7 listków w liściu w czym upatrywane jest znaczne podniesienie jakości paszy.

\section{PODSUMOWANIE I WNIOSKI KOŃCOWE}

Poznanie wymiarów cech morfologicznych stanowiących elementy struktury plonu zielonej i suchej masy roślin motylkowatych, traw i ich mieszanek głównie z udziałem lucerny mieszańcowej, umożliwi lepsze zrozumienie funkcjonowania tych wysokoplennych fitocenoz, tak w odniesieniu do kolejnych pokosów w trakcie ich ontogenezy jak i lat użytkowania rolniczego jako cennych gospodarczo roślin pastewnych. Tylko w warunkach doświadczeń polowych można uzyskać dane służące do optymalizacji składu gatunkowego mieszanek o wyrównanej w latach produktywności. Dynamika wykształcenia liczby pędów przez porównywane gatunki i mie- 
szanki zależała od sposobu siewu i kolejnego w roku pokosu. Włączenie traw do wspólnej uprawy w mieszankach z roślinami motylkowatymi, zwłaszcza lucerną i koniczyną spowodowało większe wykorzystanie ich potencjalnej produktywności w wyniku wzrostu liczby pędów i ich jednostkowej masy, co ma duże znaczenie ponieważ dodatek traw poprawia stosunek energetyczno-białkowy plonu mieszanek. Tworzenie mieszanek jest podstawową przesłanką do lepszego wykorzystania energii promieniowania fotosyntetycznie czynnego przez tak skomponowane fitocenozy upraw polowych, zbieranej częściej (pokosy) w roku, czym różnią się od wszystkich innych grup roślin rolniczych. Pozaprodukcyjne znaczenie tego faktu wyraża się również w ochronie gleb przed erozją, jak i wzrostem jej żyzności co ma duże znaczenie dla roślin następczych.

Na podstawie uzyskanych wyników można wysnuć następujące wnioski końcowe:

1. Lucerna mieszańcowa wykształcała w pokosach i latach użytkowania największą powierzchnię liści pędu i łanu w porównaniu z innymi gatunkami roślin.

2. U wszystkich gatunków wystąpiły różnice wartości cech morfologicznych w pokosach. Interakcje zachodzące między cechami morfologicznymi roślin oraz indeksem liściowym łanu wskazują na większy wpływ na nie pokosu w porównaniu do roku uprawy.

3. Większe zagęszczenie pędów w połączeniu ze wzrostem ich masy u gatunków rosnących w mieszankach w porównaniu $\mathrm{z}$ uprawą w siewie czystym świadczy o występowaniu koegzystencji pomiędzy gatunkami traw i roślin motylkowatych tworzących fitocenozę mieszanek.

\section{Literatura}

Berlinger J. E. (1984). The significance of symbiotic nitrogen fixation in plant production, CRC Critical Rev. in Plant Sci., 1, 4: 269-286.

Binderova A . (1985). Reakce nekterých nových šlechteni vojtěčky a jetele lučniho na agrotechnicke zásahy. Acta Univ. Agr. A $33(4): 171-176$.

Binderova A., Holý J. (1988). Reakce novych odrud vojtěčky na zpusob založeni a využivani porostu. Rostl. Vyr. 34 (11): 1123-1130.

Borowiecki J. (1994). Porównanie plonowania mieszanek lucerny z trawami w zależności od sposobu siewu i nawożenia azotem. Pam. puł., z 104: 89-99.

Bowley S. R., Dougherty C. T., Taylor N. L.. Cornelius P. L. (1988). Comparison of yield components of red clover and alfalfa. Can. J. Plant Sci., 68 (1): 103-114.

Dančik J., Vilček P. (1984). Vplyv zloženia a sposobu zakladania lucernotravnych a datelinotravnych miešanek na ich urodu. Rostl. V(r. 30 (3): 263-272.

Halva E.. Lesák J., Kovářik J. (1979). Produkěni schopnost krátkodobých jetelotravnich směsek na bazi tetraploidniho jetele lučniho. Acta univ. agric. (Brno) fac. agron. XXVII z 1: 51-75.

Hruškowa H. (1994). Vliv velikosti vysévaného osiva na výnos votéšky seté ve druhém a třetim roce vegetace. Rostl. V(r. 40 (10): 957-965.

Juan N. A. Sheafer C. C.,Barnes D. K., Swanson D. R., Halgerson J. H. (1993). Leaf and stem traits and herbage quality of multifoliolate alfalfa. Agron. J. 85: 1121-1127.

Jelinowska A.. Magnuszewska K. (1994). Porównanie sposobów siewu mieszanek lucerny z niektórymi gatunkami traw. I. Plonowanie i skład botaniczny. Pam. puł z. 104: 61-73.

Juszkina I. I., Niemczinowa Ł. P., Czuriewa T. W. (1985). Poslediejstnije zimnich powreźdenij na rost, razvitie i formirowanie urożaja klewiera krasnowo. Tr. NII c-ch. meterol., nr 15: 65-69. 
Käding H., Kreil W. (1982). Ergebnisse von Modellversuchen zum Einfluß der Saattiefe auf den Aufgang von Gras und Luzernesamen. Arch. Acker - u Pflanzenbau u. Bodenkd. 26 (3): 193-198.

Knoch G. (1982). Hinweise zum Anbau von Rotkleegras und zum effektiven Einsatz in der Tierproduktion. Feldwirtschaft Jg 23, H. 6: 277-279.

Kunelius H. T., Narasimhalu P. (1983). Yields and quality of Italian and Westerwolds ryegrasses, red clover, alfalfa, birdsfoot trefoil and Persian clover grown in monocultures and ryegrass - legume mixtures. Can J. Pland Sci 63 (2): 437-442.

Law J. R., Reeves J. C. (1984). The use of hand-held data terminals in national intitute of agricultural botany field trial recording. J. Nat. Inst. Agr. Bot., 16 (3): 397-413.

Lehmann J.. Meister E. (1982). Die gegenseitige Beeinflussung von Klee und Gräsern bei unterschiedlicher Stickstoffdüngung in bezug auf Wachstum. EiweiB. Rohfaser und Mineralstoffgehalt. Z. Acker und Pflanzenbau, 151 (1): 24-41.

Lichner S.. Khazim H. (1986). Vztah medzi počtom stoniek a ich hmotnostou na urodu lucerny siatej (Medicago sativa L.). Polnohospodarstwo, 32 (2): 97-104.

Lichner S.. Zapotoény V. (1984). Vplyv závlahy na výšku a stabilizáciu úrod vicaroćnich krmovin. Polnohospodarstvo, 30 (9): 799-806.

Major D. J., Hanna M. R.. Smoljak S.. Grant R. (1979). Estimating nodule activity of sainfoin alfalfa and cicer milkvetch seedings. Agron. J., 71: 644-647

Meisen C., Peters G., Kruth U. (1983). Ertragsvergleiche zwischen Rotklee, Kleegras und Welschem Weidelgras unter dem Aspect des Stickstoff und Energieaufwandes. Feldwirtschaft 24 (4): 149-151.

Moyer J. R. (1984). Effect of weed control and a companion crop on alfalfa and sainfoin establishment. yields and nutrient composition. Can. J. Plant Sci. 65: 107-116.

Posypanow G. S., Woronkowa T. W. (1983). Formirowanie urożaja, simbioticzeskaja i fotosinteczeskaja dejatielnost kliewiera lugowo 2-go goda zizni pri wniesieni azotnych udobrienii i oroszenja. Izw TSChA, nr 2: 29-35.

Prochazka J., Mrankova V., Pelikán J. (1984). Einfluss des biologischen Saattgutwertes auf die Ertrgsleistung der Luzerne im Aussatjahr. Wiss. Beitr. M-Luther-Univ: Halle - Wittenberg 42: 215-227.

Sheaffer C. C.. Marten G. C.. Rabas D. L. (1984). Influence of grass species on composition. yield and quality of birdsfoot trefoil mixtures. Agron. J. 76, (4): 627-632.

Staszewski Z. (1975). Lucerny. PWRil W-wa 335.

Zając T. (1987). Wpływ różnych terminów zbioru na wysokość i strukturę plonu suchej masy czternastu odmian lucerny mieszańcowej (Medicago media Pers.). Zesz. Nauk. AR w Krakowie. Rolnictwo z. 27: 205-221.

\section{Streszczenie}

Przeprowadzone w latach 1994-96 badania miały na celu analizę cech morfologicznych wieloletnich roślin motylkowatych i traw wysianych w czystym siewie (6 obiektów) i mieszankach (3 obiekty). Uwzględniono następujące cechy morfologiczne: liczba pędów na $1 \mathrm{~m}^{2}$, masa pojedynczego pędu, liczba liści na pędzie, powierzchnia liści pędu $-\mathrm{cm}^{2}$ oraz dwie charakterystyki łanu: liczba liści na $1 \mathrm{~m}^{2}$ oraz indeks powierzchni liściowej $-\mathrm{m}^{2} \times \mathrm{m}^{2}$.

Doświadczenie zlokalizowano na czarnoziemie zdegradowanym, sprzyjającym dobremu wzrostowi wszystkich roślin, które corocznie zbierano w trzech pokosach, $w$ fazie zakwitania lucerny.

W wyniku przeprowadzonych badań stwierdzono, że lucerna mieszańcowa wykształcała w pokosach i latach uprawy największą powierzchnię liści pędu i łanu w porównaniu $z$ innymi gatunkami roślin.

W wyniku różnic gatunkowych oraz sposobu siewu wszystkie cechy były istotnie zróżnicowane. Interakcje zachodzące między cechami badanych gatunków i charakterystykami łanu wskazują na znacznie większy wpływ pokosu w porównaniu do wpły- 
wu wywieranego przez lata uprawy, który okazał się wyraźny tylko w odniesieniu do indeksu powierzchni liści łanu. Większe zagęszczenie pędów roślin uprawianych w mieszankach w porównaniu z uprawą w siewie czystym świadczy o występowaniu koegzystencji pomiędzy gatunkami traw i roślin motylkowatych tworzących fitocenozę mieszanek, szczególnie widoczne w mieszankach z lucerny, koniczyny, kostrzewy i życicy.

Podziękowania, które pragnę przekazać pani Katarzynie Hryniewieckiej wiąż się z trudem włożonym w wykonanie rysunków. Magistrowi inż. Markowi Kołodziejczykowi dziękuję za pomoc w obliczeniach statystycznych oraz edycji tekstu. Dziękuję pracownikom technicznym ZSzUR za analizy biometryczne roślin, których przeprowadzenie wymagało wiele wysitku. 